\title{
運動視標追従時の随従性眼球運動と 跳躍性眼球運動の発生に関する実験的検討
}

○福田亮子(慶應義熟大学大学院), 中村悦夫(竹井機器工業株式会社), 佐久間美能留(慶應義熟大学大学院), 福田忠彦(慶應義熟大学環境情報学部)

Experimental Analysis of Eye Movement during Tracking a Moving Target

$$
\begin{gathered}
\text { Ryoko Fukuda(Keio Univ.), Etsuo Nakamura(Takei, Co. Ltd.), } \\
\text { Minoru Sakuma, Tadahiko Fukuda(Keio Univ.) }
\end{gathered}
$$

\section{1 はじめに}

ある速度をもって運動する視標を目で追う 場合には随従性眼球運動と跳躍性眼球運動が 生じる。従来の知見から、視標の速度が低速 である場合には随従成分が主であり、高速に なるほど跳躍運動成分の占める割合が大きく なるということがわかっているが、本研究で は注視点を定義するための基礎として両者の 挙動について詳細な検討を行った。

\section{2 実験方法}

CRT画面上に一定速度で移動する点視標を提 示し、これを目で追ったときの眼球運動を眼 球運動測定装置(EYE MOVEMENT MONITOR; (株)竹井機器工業)で測定した。サンプリング は10msecで、視線位置と視標の位置を同時 に入力・記録した。視距離は $40 \mathrm{~cm} 、 \mathrm{CRTディ}$ スプレイの大きさは21インチである。

刺激の視標は画面中央から左に10degの位置 で2sec点灯した後、右方向に一定速度で直線 運動し、中央から右に10degの位置で消灯す る。移動速度は5，15，20，30deg/secの4種類 で、各速度につき3回の試行を行った。

被験者にはあご台を使用し顔面を固定した上 で、ディスブレイ上に現れる視標を目だけで 追うように指示した。被験者は大学生・大学 院生6名である。

\section{3 結果と考察}

得られた結果を眼球運動の速度の面から分析 した。

\section{1 視線移動速度の分布}

被験者ごとに視標の各速度について3試行分 のデータをまとめ、眼球運動速度のヒストグ ラムを作成すると(図1)、視標の移動速度が $5 \mathrm{deg} / \mathrm{sec}$ の場合にはマイナスの成分と $50 \mathrm{deg} / \mathrm{sec}$ 以上の成分を除けば、5deg/sec付 近にピークを持つ単峰型のグラフとなる。し かし、15deg/sec以上の速度の場合には、ヒ ストグラムにはいくつかのピークが現れる。
$5 \mathrm{deg} / \mathrm{sec}$

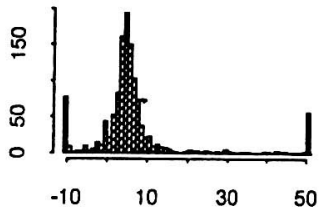

$20 \mathrm{deg} / \mathrm{sec}$
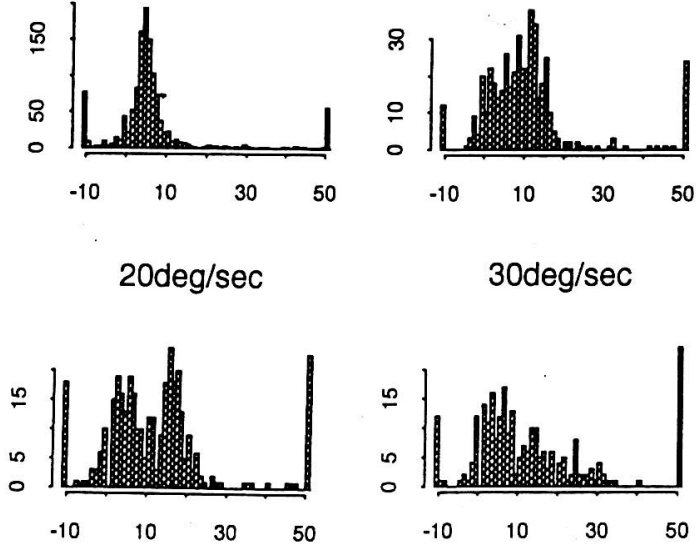

$30 \mathrm{deg} / \mathrm{sec}$
図1視標の各速度における

眼球運動速度のヒストグラム

(縦軸はデー夕数を、横軸は視線の移動速度

(単位:deg/sec)を表す。) 
一つは5deg/secの場合と同样、 $5 \mathrm{deg} / \mathrm{sec}$ 付近、 そしてもうーつは視標の速度付近である。た だし、30deg/secの場合には30deg/sec付近の 成分はほとんどないか、あってもかなり少な い。これは30 deg/secという速度では安定し て視標を追うことが困難であることを示して いる。すなわち、随従運動成分は最大でも $30 \mathrm{deg} / \mathrm{sec}$ 程度であるということが示唆され る。また、これらの各運動成分は、 $5 \mathrm{deg} / \mathrm{sec}$ 付近をピークとする注視成分、提示される視 標の速度付近をピークとする随従成分、それ よりも高速な跳躍成分の3つに分類すること が可能であると考えられる。

\section{2 跳唯成分の割合}

$50 \mathrm{deg} / \mathrm{sec}$ 以上の跳躍運動と見られる成分の 割合は視標の速度により異なり、視標の速度 が速いほど多くなった。各試行における跳躍 運動成分の割合を図2に示す。

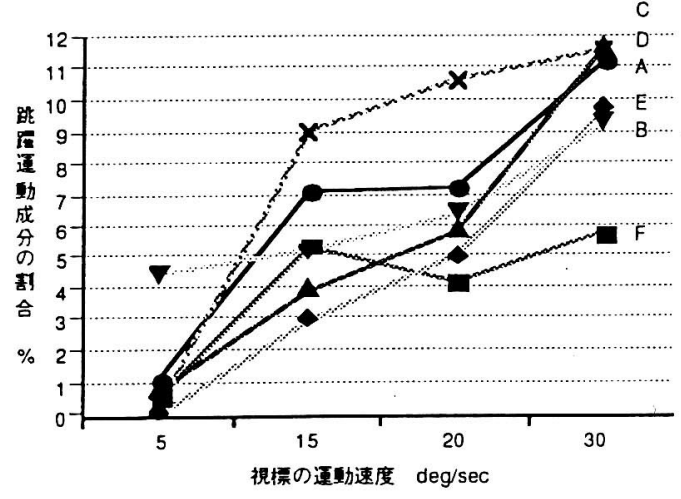

図2 各試行における50deg/sec以上の

跳躍運動成分の割合

このような高速の跳躍運動成分の速度は視 標の速度が速いほど速いものが多くなる。そ の平均值は視標の速度が $5 \mathrm{deg} / \mathrm{sec}$ c場合は 60 〜 70 deg/sec程度であるのに対し、30 deg/sec の場合は150deg/sec以上となっており、最高 值も5deg/secではたかだか100deg/secである が、30deg/secになると400 deg/secにも達す る。

\section{3 マイナスの運動成分}

視標がー方向に運動している場合でも反対 方向の運動成分、すなわちマイナスの速度を 持つ運動成分が存在するということも大きな 特徵として挙げることができる。速度の変化 を時系列グラフにすると、マイナスの運動は 必ず大きな跳躍運動の後に現れており、視標 よりも視線が行き過ぎししった場合に位置 を㭪正する役割を果たしているものと考えら れる(図3)。

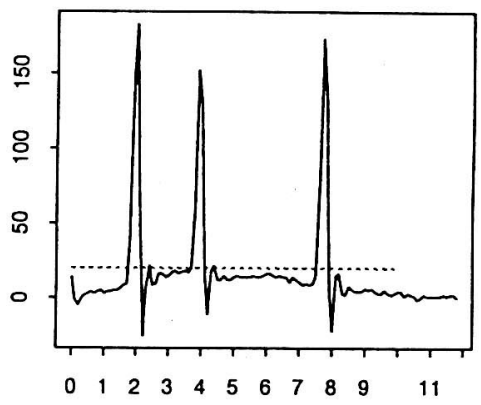

図3 時系列グラフ (視標速度20 deg/sec)

(縦軸は視線の移動速度(単位:deg/sec),

横軸は経過時間(1目盛は $100 \mathrm{msec}$ )を表す)

\section{4 まとめ}

運動する視標を目で追ったときの眼球運動に は注視成分、随従運動成分、跳躍運動成分の 3つの成分が含まれる。しかし、これらの運 動成分の境界速度は視標の運動速度によって 異なる。よって、眼球運動の分析、あるいは 眼球運動データをもとにした注視点の分析を 行う場合には、視対象の運動速度に留意し、 それぞれの刺激に適した眼球運動成分の定義 を行う必要がある。

今後はさらにほかの速度や方向についても同 様の実験を行い、運動視摽追従時の眼球運動 の総合的特性を明らかにし、注視点の定義に 関して新しい提案をしたいと考えている。

本研究は文部省科研費一般研究(B)の援助を 得て遂行された。 